\title{
Research on the Cultivation of College Students' Innovative Ability
}

\author{
Huang Jian \\ Xijing University, Xi’an 710123, China \\ 565200245@qq.com
}

Keywords: Second class; Interest group; Creative Ability

\begin{abstract}
This paper probes into the cultivation methods of College Students' innovative ability, and proposes to arouse students' interest by means of "interest groups" or "second classes". Guide teachers to carry out theoretical training and project training, and improve students' practical ability. When students have certain practical ability, they develop independently. According to their own interests and hobbies, through the consultation of information, collect information, put forward some new ideas, and strive to achieve it.
\end{abstract}

\section{Introduction}

In the economic globalization, international background of increasingly deep progress of science and technology change rapidly, the increasingly fierce international competition, the Party Central Committee and the State Council made a major strategic decision to adhere to independent innovation and building an innovative nation. As an important component of the national innovation system, colleges and universities must renew their ideas in an all-round way and take the cultivation of students' innovative ability as the core of the educational reform.

As a private college based on engineering, our school has responded positively to the call of the state. The training target of students is defined as "innovative and applied talents"'". Many platforms have been set up in our university, focusing on the cultivation of innovative ability of Engineering students. For example, the establishment of innovative training centers for college students, encourage students to participate in University projects, such as large projects.

In the classroom building not only to the first classroom teaching as the basis, give full play to the role of the main channel of classroom teaching, the innovation of science and technology education throughout the whole process of personnel training; we must attach importance to the important channel of the second class education, active docking and extension of the first class content, through innovative educational activities, extracurricular activities, discipline competition, cooperation and two classroom activities, the system of training engineering students' innovative ability.

Based on Marx's view of practice as the theoretical basis, through the analysis of engineering students' innovative ability, the relationship between Li Qingdi and the culture of the two classroom activities of engineering students' innovative ability, for the construction of the second classroom training the main problems in engineering students' innovative ability from, and finally explore the proposed norms in the construction of the second classroom on the basis. With professional associations, extracurricular activities, academic competitions, school enterprise cooperation as to cultivate students' practical ability and innovation ability of second classroom activity platform.

\section{How to improve the ability of college students.}

How to improve the quality of college students, especially the cultivation of innovative ability, has become an important subject for colleges and universities in the twenty-first Century. As students of engineering departments, it is more worthy of our attention to develop skills and cultivate innovative ability. In particular, the development of the second class has a special significance and advantage in the cultivation of students' innovative ability.

The course of SCM principle is a required course for college majoring in electrical, SCM 
emphasizes the application and practice, is one of the essential skills class student employment, and SCM development ability often become many companies recruit students majoring in electrical standards.

In the economic globalization, international background of increasingly deep progress of science and technology change rapidly, the increasingly fierce international competition, the Party Central Committee and the State Council made a major strategic decision to adhere to independent innovation and building an innovative nation. As an important component of the national innovation system, colleges and universities must renew their ideas in an all-round way and take the cultivation of students' innovative ability as the core of the educational reform.

As a private college based on engineering, our school has responded positively to the call of the state. The training target of students is defined as "innovative and applied talents"'. Many platforms have been set up in our university, focusing on the cultivation of innovative ability of Engineering students. For example, the establishment of innovative training centers for college students, encourage students to participate in University projects, such as large projects.

In the classroom building not only to the first classroom teaching as the basis, give full play to the role of the main channel of classroom teaching, the innovation of science and technology education throughout the whole process of personnel training; we must attach importance to the important channel of the second class education, active docking and extension of the first class content, through innovative educational activities, extracurricular activities, discipline competition, cooperation and two classroom activities, the system of training engineering students' innovative ability.

Based on Marx's view of practice as the theoretical basis, through the analysis of engineering students' innovative ability, the relationship between Li Qingdi and the culture of the two classroom activities of engineering students' innovative ability, for the construction of the second classroom training the main problems in engineering students' innovative ability from, and finally explore the proposed norms in the construction of the second classroom on the basis. With professional associations, extracurricular activities, academic competitions, school enterprise cooperation as to cultivate students' practical ability and innovation ability of second classroom activity platform.

How to improve the quality of college students, especially the cultivation of innovative ability, has become an important subject for colleges and universities in the twenty-first Century. As students of engineering departments, it is more worthy of our attention to develop skills and cultivate innovative ability. In particular, the development of the second class has a special significance and advantage in the cultivation of students' innovative ability.

The course of SCM principle is a required course for college majoring in electrical, SCM emphasizes the application and practice, is one of the essential skills class student employment, and SCM development ability often become many companies recruit students majoring in electrical standards.

The research group believes that the application of personnel training should be objective, scientific and perfect assessment system, so as to promote the reform of evaluation, so that the application of talents training to receive better results. Such as the establishment of evaluation of the ability of logical thinking, image thinking ability and creative thinking ability of evaluation index, evaluation method, comprehensive quality and establishing innovation ability of creative design evaluation methods and evaluation method of teaching feedback.

The cultivation of Applied Talents in the professional teaching, the research group that occupy basic position in the teaching of professional courses to cultivate applied talents, which is determined by the cultivation of applied talents of the function of the applied talents training ability to provide a good basis for the professional teaching, incentives for professional teaching note emotional person, provides effective teaching methods for teaching. Therefore, in the teaching way to strengthen the composition of training applied talents are two: one is to strengthen the research on the professional course itself, identify the entry point to fully tap the professional teaching and the cultivation of applied talents is closely related; two which is "Tao" to "industry", strengthen the application of talents training an important function in teaching in. 


\section{Summary}

The cultivation of applied talents is not subject education, but comprehensive education and all-round development education. It is the education of improving the quality of talents as the main content and purpose. The applied talents through the military training of the students, "Two Courses" in social practice (survey), moot court, legal advice, legal practice thematic debates, graduation practice and graduation thesis writing exercise, in order to achieve the purpose of improving the ability of social adaptation. Therefore, the construction of a scientific and rational training curriculum system for applied talents must be based on the curriculum content of specialized courses, so that the cultivation of professional and applied talents can be organically integrated. Such as the use of mock court, should be in the "criminal law", "civil law", "law of law" and other courses of the organic combination; graduation practice and thesis writing as much as possible covering the main courses of law. In addition, in the long run, we can specialize in the teaching materials in this field and provide a better theoretical basis for the training of application-oriented talents.

\section{References}

[1] Tang Weibing, Fu Yuanhai, Wang Zhanxiang. And the transformation of economic growth mode of [J] technology innovation, economic research,.2014,7:31-42.

[2] Bai Junhong, Chiang Kai Shek. Collaborative innovation, spatial correlation and regional innovation performance [J], economic research,.2015,7:174-187.

[3] Lu Tong, Dang Yin. Corporate governance and technological innovation: a comparative study of sub sectors, [J], economic research,.2014,6:115-128.

[4] Li Wenlian, Xia gang. Business model innovation based on "big data" [J], China industrial economy,.2013,5:83-95.

[5] Cheng Cheng. Research on enterprise value network innovation under Internet economy [J] China industrial economy.2013,9:82-94. 